\title{
Comparison of Proliferation and Motile Activity Between Human Keratinocytes Isolated from Skin and Oral Mucosa*
}

\author{
Justyna DruKAŁA, Joanna ZARZECKA, Katarzyna GoJNICZEK, Agnieszka WALIGÓRSKA, \\ Jan ZAPAŁA and Włodzimierz KOROHODA
}

Accepted January 25, 2005

\begin{abstract}
DrukaŁa J., ZarZecka J., GojnicZeK K., WaLigórska A., ZapaŁa J., Korohoda W. 2005. Comparison of proliferation and motile activity between human keratinocytes isolated from skin and oral mucosa. Folia biol. (Kraków) 53: 21-28

Objective: Epithelial wound repair assures the recovery of the epithelial barrier after wounding. During wound healing epithelial cells migrate to cover the wound surface. For healing of skin wounds the skin keratinocytes can be replaced by oral mucosa epithelial cells grown in vitro. The presented experiments were carried out in order to compare the proliferation, morphology, and migration between human keratinocytes isolated from human skin and oral mucosa. Materials and methods: Human epidermal and oral mucosa keratinocytes from primary culture were used in all experiments. Cell motility and shape were determined using computer-aided methods. Results and conclusions: It was demonstrated that although both cell types exhibit the same typical epithelial morphology, oral mucosa keratinocytes locomote significantly faster than skin keratinocytes. They also differ in proliferation activity. Oral mucosa keratinocytes exhibited faster growth and different actin cytoskeleton organisation than skin keratinocytes under in vitro conditions. Autologous oral mucosa keratinocytes may be expanded in vitro and used for skin wound healing in vivo.

Key words: Cell migration, proliferation, keratinocytes, skin, oral.

Justyna DRUKAEA, Katarzyna GOJNICZEK, Agnieszka WALIGÓRSKA, Włodzimierz KOROHODA, Laboratory of Cell and Tissue Engineering, Department of Cell Biology, Faculty of Biotechnology, Jagiellonian University, Gronostajowa 7, 30-387 Kraków, Poland.

E-mail: justyna@mol.uj.edu.pl

Joanna ZARZECKA, Laboratory of Conservative Dentistry and Endodontics, Institute of Dentistry, Medical College, Jagiellonian University, Montelupich 4, 31-155 Kraków, Poland.

Jan ZAPAEA, Department of Maxillofacial Surgery, Jagiellonian University, os. Ztotej Jesieni 1, 31-826 Kraków, Poland.
\end{abstract}

Keratinocytes are the dominating cell type in the epithelium of human skin and in oral mucosa. Many potential clinical applications of grafts of cultured epithelial cells have been recognized since their first application in management of burn patients (O'CONNOR et al. 1981). They can be used for the treatment of burns and some skin diseases, and also in the surgical repair of human skin or mucosal defects (DRUKALA et al. 2001; GALLICO et al.1989; KAISER et al.1994; LAUER 1994; RONFARD et al. 1991; SUGIMURA et al.1997; UEDA 1995). The advantage of skin reconstruction with cultured epithelium is that a large epithelial sheet or cell suspensions can be obtained in vitro from a small biopsy of skin. It has been shown that oral mucosa epithelial cells can be cultured in vitro in the same way as keratinocytes isolated from skin (NISHIMURA et al. 1996; UEDA 1995).

Epithelial wound repair assures recovery of the epithelial barrier after wounding. An important goal in wound management is, therefore, to achieve rapid wound closure. The restoration of tissue structure and function after wounding occurs by the activation of keratinocytes which induces migration, proliferation, and differentiation. The cells involved in primary wound closure originate from the adjacent epithelium. They migrate as keratinocyte sheets and gradually differentiate (BEREITER-HAHN 1986; GRINNELL 1990).

Mucosal epithelial culture as a new source of epithelial cells for skin repair was first described by UEDA et al. in a clinical report (KAISER et al. 1994; 
UEDA 1995). It has been shown that the grafts survived and formed normal skin in the recipient sites.

The experiments presented in this article were carried out on human keratinocytes isolated from skin and oral mucosa in order to compare their migration, morphology, and proliferation. It was also examined whether conditioned medium from fibroblast cultures added to the cultured medium influences movement and proliferation of oral mucosal keratinocytes.

\section{Material and Methods}

\section{Materials}

The following chemicals were purchased from the sources indicated: keratinocyte serum free medium KBM-2 supplemented with BPE (bovine pituitary extract), hEGF, insulin, hydrocortisone, transferrin, epinephrine, gentamycin (CLONETICS, San Diego, USA), phosphate buffered saline w/o Ca ${ }^{2+}$ and $\mathrm{Mg}^{2+}$ (PBS), Dulbecco's Modified Eagle's Medium (DMEM), dispase, $0.05 \%$ trypsin $/ 0.53 \mathrm{mM}$ EDTA solution, gentamycin, foetal bovine serum (FBS) (GIBCO Laboratories, Grand Island, NY, USA), phalloidin-conjugated tetra- methylrhodamine B isothiocyanate (TRITC-phalloidin) (Sigma, St. Louis, USA). Culture flasks and plates were purchased from Corning (London, UK).

\section{Cell culture}

Keratinocytes from skin and oral mucosa were isolated in the same way. Human keratinocytes (epithelial cells) were isolated from a skin or buccal mucosa biopsy taken from healthy donors, during plastic surgery (6 patients operated for facial cosmetic reasons; women, 35-45 yr; average 40) or operation of sinus maxillaries ( 6 patients; 4 men and 2 women, $35-45 \mathrm{yr}$; average 40 ). Informed consent and Ethical Committee approval were obtained according to Polish law (No. KBET/480/B/2003 and KBET/509/B/2003). A $0.5 \mathrm{~cm}^{2}$ skin or mucosa biopsy was rinsed 3 times in calcium- and magnesium-free PBS supplemented with gentamycin $(100 \mu \mathrm{g} / \mathrm{mL})$. After washing, the biopsy was placed in PBS containing dispase $(12 \mathrm{U} / \mathrm{mL})$ for $16 \mathrm{~h} \mathrm{in} 4{ }^{\circ} \mathrm{C}$. Next, subcutaneous tissue was removed and epithelium was treated with $0.05 \%$ trypsin for 10 min to isolate epithelial cells. The enzyme activity was eliminated by dilution with KBM-2. The cell suspension was then centrifuged for $5 \mathrm{~min}$ at $100 \mathrm{~g}$ and the cell pellet was resuspended in KBM-2 serum free medium. When the primary culture of keratinocytes in wells reached $40-50 \%$ of confluence (after 5-6 d), the keratinocytes were passaged to expand the culture. The keratinocytes were detached by incubation with $0.05 \%$ trypsin. After 5 min incubation trypsin was diluted with KBM-2 medium (1:5). The keratinocytes were pelleted by centrifugation and resuspended in KBM-2 medium for passaging the cells. The cells were then plated at an initial cell density of $10^{4}$ cells per $1 \mathrm{~cm}^{2}$ and grown to $70 \%$ of confluency. In all the cell cultures the medium was changed every $48 \mathrm{~h}$ and cells were cultured in a humidified atmosphere with $5 \% \mathrm{CO}_{2}$ at $37^{\circ} \mathrm{C}$ (DRUKALA et al. 2001).

\section{Isolation and culture of oral mucosa fibroblasts}

After dispase treatment, subcutaneous tissue was transferred into enzyme solution containing trypsin $(0.05 \%)$ and collagenase $(0.05 \%)$ and incubated for about $30 \mathrm{~min}$ in $37^{\circ} \mathrm{C}$ allowing dissociation of tissue. The enzyme activity was eliminated by adding DMEM containing 10\% FBS supplemented with gentamycin $(100 \mathrm{mg} / \mathrm{mL})$. The cell suspension was then centrifuged for $5 \mathrm{~min}$ at $100 \mathrm{~g}$ and the cell pellet was resuspended in DMEM containing $10 \% \mathrm{FBS}$ supplemented with gentamycin $(100 \mathrm{mg} / \mathrm{mL})$ and placed into culture flasks at a density of 10000 cells per $1 \mathrm{~cm}^{2}$.

\section{Preparation of conditioned medium}

Fibroblast was cultured in DMEM supplemented with $10 \%$ FBS and gentamycin. Conditioned medium $(\mathrm{CM})$ was prepared by incubating the confluent fibroblast with KBM-2 (without supplements) medium at $37{ }^{\circ} \mathrm{C}$ overnight. After this incubation conditioned medium were collected and used in experiments.

\section{Cell proliferation measurement}

Cells were cultured in culture flasks. Initial density was $10^{4}$ cells $/ \mathrm{cm}^{2}$. The cell number was calculated 24, 48, and $72 \mathrm{~h}$ after culture initiation. Cells were harvested from culture flasks by trypsinization; the number of cells was determined using Bürker's haemocytometer.

Evaluation of cell morphology - measurements of cell size and shape

After $12 \mathrm{~h}$ of incubation of skin and oral mucosa keratinocytes in control medium, the images were recorded digitally and processed. Cell image analysis was performed using a system consisting of an inverted microscope equipped with a Hitachi KP-161 CCD camera, a PC computer, a frame grabber, and CYTOCYCLE 2.0 program for image analysis (by $\mathrm{R}$. TOKARSKI). The image of each cell was binarized. Cell contours were used for determination of the following cell shape parameters: projected surface area (in $\mu \mathrm{m}^{2}$ ); perimeter of projected area (in 
$\mu \mathrm{m})$; extension, this being a measure of how much the shape differs from a circle (the extension for a circle is zero and increases as the shape becomes less compact; the extension is a sum of elongation and dispersion); dispersion, this being the minimum extension that can be attained by compressing the shape uniformly; and elongation of the cell, this being a measure of how much the shape must be compressed along its long axis in order to minimise its extension. The shape parameters were defined and calculated as described by DUNN and BROWN 1987).

\section{F-actin cytoskeleton staining}

For visualization of F-actin the cells grown on glass slides were fixed in $3.7 \%(\mathrm{w} / \mathrm{v})$ paraformaldehyde in PBS ( $\mathrm{pH}$ 7.2) for $10 \mathrm{~min}$ at room temperature. After rinsing in phosphate-buffered saline (PBS) the cells were permeabilized with $0.1 \%$ Triton $\mathrm{X}-100$, again rinsed in PBS. For visualization of Factin the cells were incubated in $20 \mu \mathrm{L}$ TRITC-labeled phalloidin (in the concentration of $500 \mathrm{ng} / \mu \mathrm{L}$ ) in darkness for 1 hour at $37^{\circ} \mathrm{C}$ in a humidified incubator. Thereafter, the cells were rinsed in PBS and observed on a Leitz Wetzlar-fluorescence microscope.

Time-lapse monitoring of movement of individual cells

Images of migrating keratinocytes were recorded and analysed by computer-aided methods (KOROHODA et al. 1997; KOROHODA \& MADEJA 1997; SOLL 1995). Cells from secondary cultures were observed $24 \mathrm{~h}$ after plating at a density of $10^{4}$ cells $/ \mathrm{cm}^{2}$ into tissue culture Falcon Petri dishes. Tracks of individual locomoting keratinocytes were generated by determination of cell centroid displacements with time-lapse images taken at 3 min intervals during a total observation period of $120 \mathrm{~min}$. The positions of the keratinocyte centroid were marked by an observer on a digitized image. 100 cell tracks were recorded under each of the experimental conditions tested. The cell trajectories were presented in circular diagrams with the starting point of each trajectory situated in the diagram centre (GRULER \& NUCITELLI 1991). The following parameters characterizing cell locomotion were computed for each cell using procedures written in the Mathematica language, including:

a - total length of cell trajectory (in $\mu \mathrm{m}$ ); the trajectory was a sequence of $\mathrm{n}$ straight-line segments, each corresponding to cell centroid translocation within one time interval between two successive images;

$\mathrm{b}$ - total length of the final displacement of the cell from the starting point to the final position, i.e. distance between the first and last points of the cell track (in $\mu \mathrm{m}$ ); $\mathrm{c}$ - average speed of cell locomotion defined as total length of cell trajectory/time of recording (LEE et al. 1994)

$\mathrm{d}$ - the ratio of cell displacement length to cell trajectory length, called the coefficient of dislocation efficiency - CDE (FRIEDL et al. 1993; NISHIMURA et al. 1996; SHERIDAN et al. 1996; WÓJCIAK-STOTHARD et al. 1995).

\section{Microphotography}

Microphotographs were taken under a Hund inverted microscope with a phase contrast equipped CCD camera.

\section{Statistical analysis}

Statistical analyses were done using the Students $t$-test; $\mathrm{P}<0.05$ was considered statistically significant.
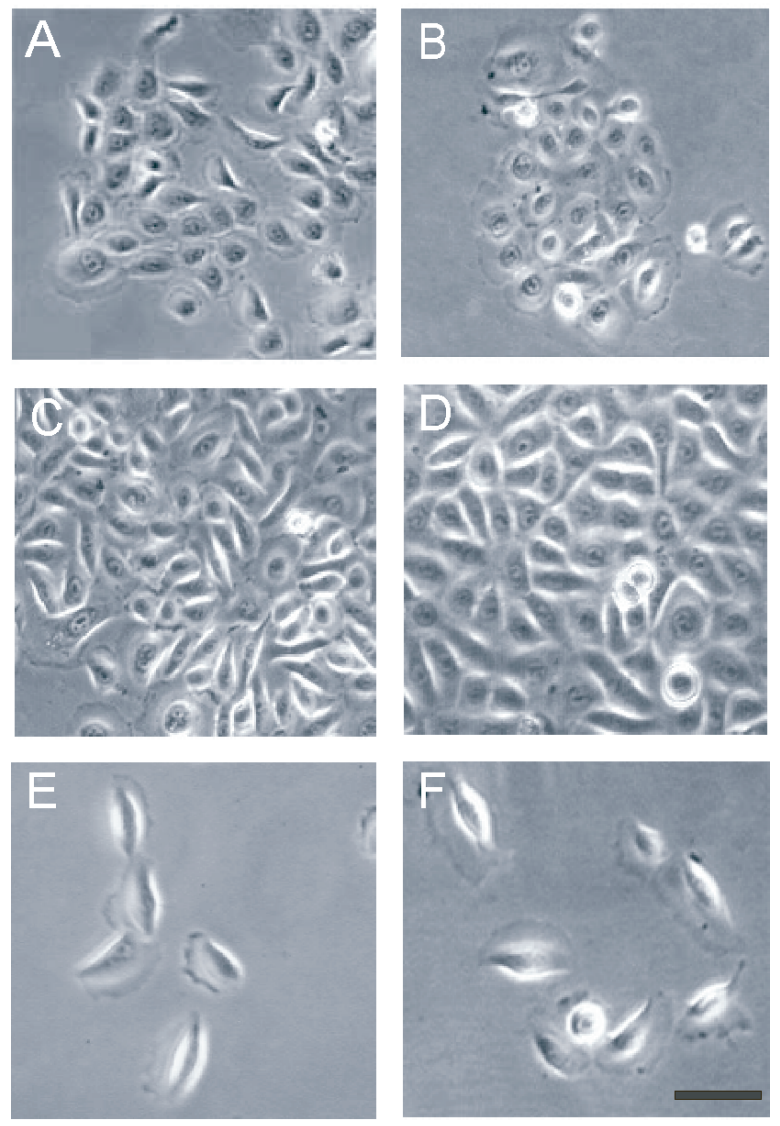

Fig. 1. Morphology of human keratinocytes isolated from epidermis $(A, C, E)$ and oral mucosa $(B, D, F)$ in control conditions. Note characteristic polarity in shape of migrating cells (E,F). Microphotographs were taken under a Nikon microscope with phase-contrast equipped with a CCD Hitachi camera, Bar $=50 \mu \mathrm{m}$.

Top panel - subconfluent cultures 3 days after passage; middle panel - confluent cultures 6 days after passage; bottom panel -24 hours after passage. 
Table 1

Morphological parameters describing the size and shape of keratinocytes isolated from skin and oral mucosa

\begin{tabular}{||l|c|c||}
\hline \multicolumn{1}{|c|}{ Parameters } & $\begin{array}{c}\text { Skin } \\
\text { keratinocytes }\end{array}$ & $\begin{array}{c}\text { Oral mucosa } \\
\text { keratinocytes }\end{array}$ \\
\hline \hline Mean cell surface area $\left[\mu \mathrm{m}^{2}\right]$ & $1639 \pm 472$ & $1618 \pm 481^{\mathrm{NS}}$ \\
\hline Mean extension & $0.92 \pm 0.29$ & $0.94 \pm 0.28^{\mathrm{NS}}$ \\
\hline Mean dispersion & $0.046 \pm 0.0048$ & $0.03 \pm 0.004^{\mathrm{NS}}$ \\
\hline Mean elongation & $0.86 \pm 0.27$ & $0.90 \pm 0.27^{\mathrm{NS}}$ \\
\hline
\end{tabular}

Note: Values are given as the mean $(n=100) \pm$ SEM.

Elongation is the measure of how much the shape must be compressed along its long axis to minimize its extension (DUNN \& BROWN 1986). Dispersion is the minimum extension that can be attained by compressing the shape uniformly. Extension is a measure of how much the shape differs from a circle. It takes a zero value if the shape is circular and increases without limit as a shape becomes less compact. All values are not significantly (NS) different from skin keratinocytes - control at $\mathrm{P}<0.05$.

\section{Results}

Comparison of morphology of keratinocytes isolated from oral mucosa and from epidermis

The cellular morphology of keratinocytes isolated from epidermis and oral mucosa is shown in Fig. 1. Both cell types exhibit typical epithelial morphology. 100 cells from each culture of both cell types were used for determination of parameters characterising cell morphology. The average projected cell surface areas in both types of keratinocytes are shown in Fig. 2A and Fig. 2B. The average values and their distribution for parameters characterising cell shape (elongation, dispersion and extension) do not differ significantly in both cell types (Table 1).
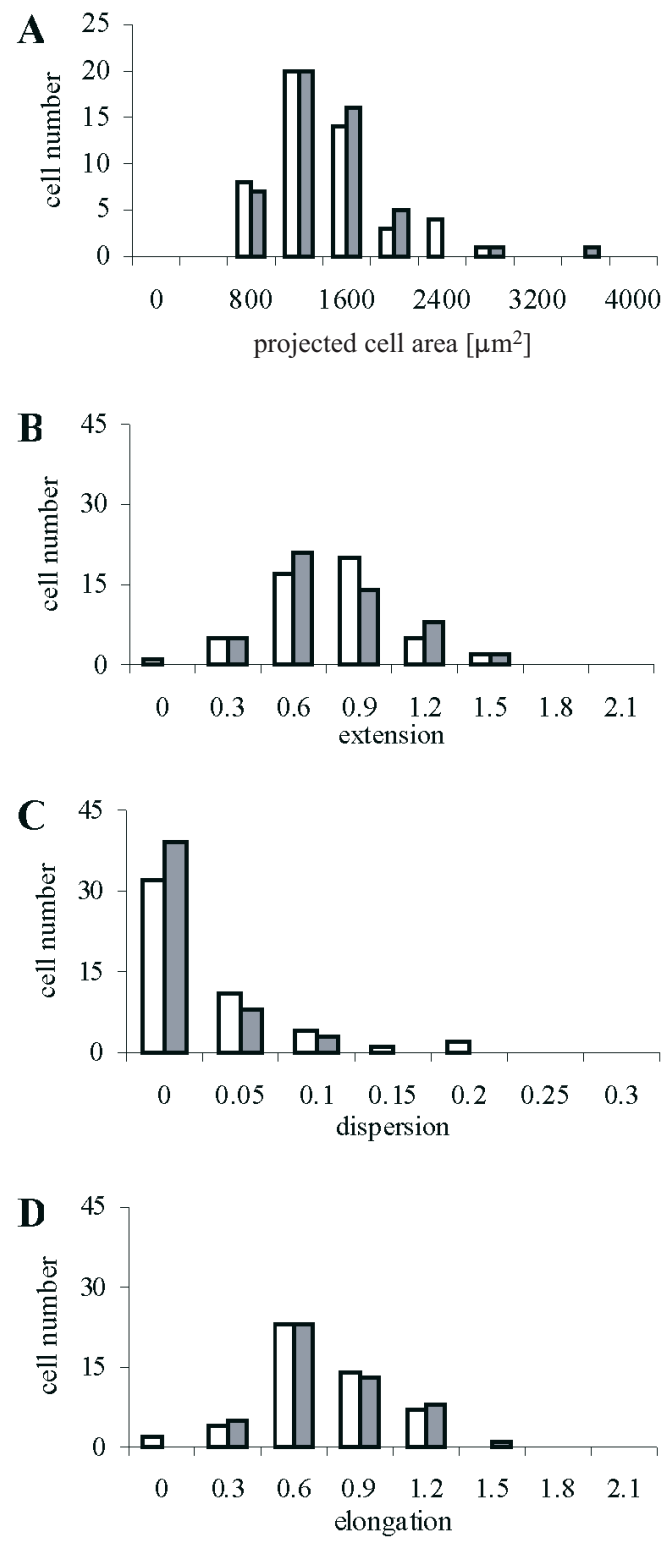

Fig. 2. Histograms showing the distribution of values of parameters used to characterize cell size and shape; (a) cell surface area, (b) extension, (c) dispersion, (d) elongation for keratinocytes isolated from epidermis (open columns) and from oral mucosa (dark columns).
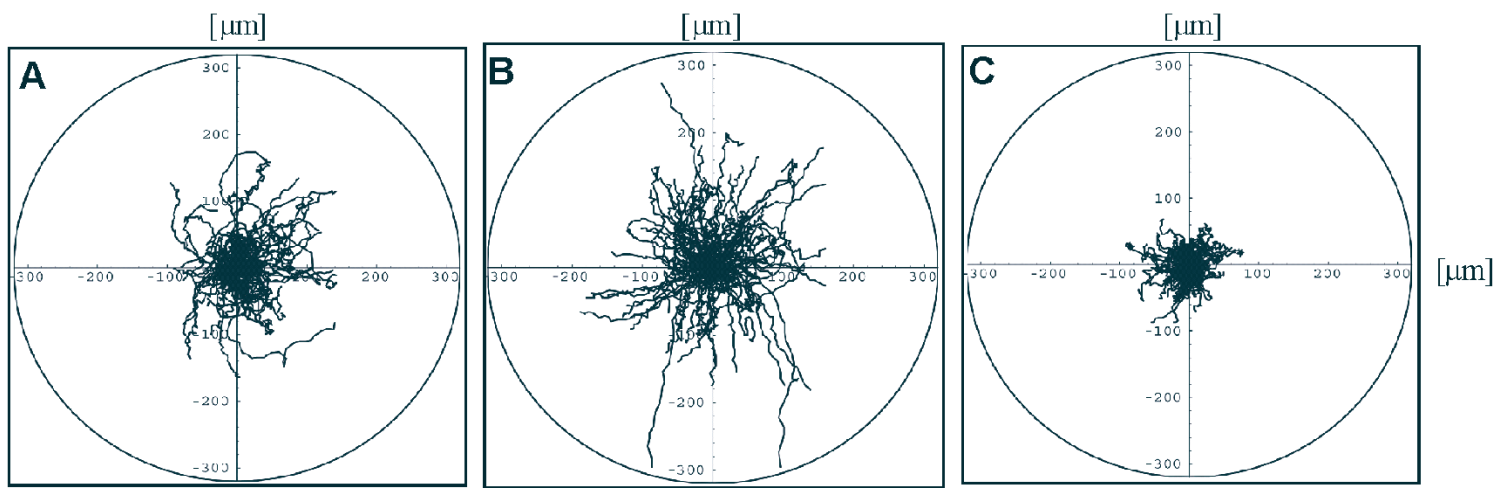

Fig. 3. Trajectories of 100 locomoting human keratinocytes isolated (A) from skin (B) from oral mucosa, (C) from oral mucosa migrating in conditioned medium prepared by incubating the confluent human mucosa fibroblasts in keratinocyte growth medium at $37^{\circ} \mathrm{C}$ overnight, displayed in circular diagrams drawn with the initial point of each trajectory placed at the origin of the plot. The images were recorded for $120 \mathrm{~min}$ and the positions of cell centroids were determined at 3 min time intervals. 
Table 2

Parameters characterizing the movement of human keratinocytes isolated from skin and oral mucosa in secondary culture

\begin{tabular}{||l|c|c|c||}
\hline \multirow{2}{*}{\multicolumn{1}{|c|}{ Parameters }} & Skin keratinocytes & \multicolumn{2}{c||}{ Oral mucosa keratinocytes } \\
\cline { 2 - 4 } & \multicolumn{2}{|c|}{ Control medium } & Conditioned medium \\
\hline \hline Total length of cell trajectory $(\mu \mathrm{m})$ & $185.56 \pm 4.87$ & $207.24 \pm 4.81^{*}$ & $148.36 \pm 3.12^{* *}$ \\
\hline Average speed of cell movement $(\mu \mathrm{m} / \mathrm{min})^{a}$ & $1.55 \pm 0.04$ & $1.73 \pm 0.04^{*}$ & $1.24 \pm 0.03^{* *}$ \\
\hline Total length of final cell displacement $(\mu \mathrm{m})$ & $67.99 \pm 4.48$ & $113.58 \pm 6.23^{*}$ & $36.49 \pm 2.07^{* *}$ \\
\hline Average rate of cell displacement $(\mu \mathrm{m} / \mathrm{min})^{b}$ & $0.57 \pm 0.04$ & $0.95 \pm 0.05^{*}$ & $0.3 \pm 0.02^{* *}$ \\
\hline Coefficient of dislocation efficiency $(\mathrm{CDE})^{c}$ & $0.36 \pm 0.02$ & $0.55 \pm 0.02^{*}$ & $0.26 \pm 0.01^{* *}$ \\
\hline
\end{tabular}

Note: Values are given as the mean $(\mathrm{n}=100) \pm \mathrm{SEM}$.

${ }^{a}$ The average speed of cell locomotion is defined as the total length of cell trajectory/time of recording $(2 \mathrm{~h})$

$b$ The average rate of cell displacement is defined as the total length of cell displacement from the starting point to the final cell position/time of recording $(2 \mathrm{~h})$

${ }^{c}$ The ratio of cell displacement to cell trajectory length. CDE would equal 1 for the cell moving persistently along one straight line in one direction and 0 for a random movement (FRIEDL et al. 1993; WÓJCIAK-STOTHARD et al. 1995).

*statistically significant versus skin keratinocytes - control medium at $\mathrm{P}<0.05$

** statistically significant versus oral mucosa keratinocytes - control medium at $\mathrm{P}>0.05$.

Epidermal keratinocytes - control conditions

A

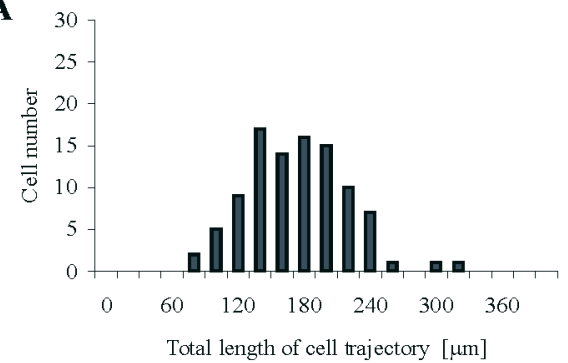

D

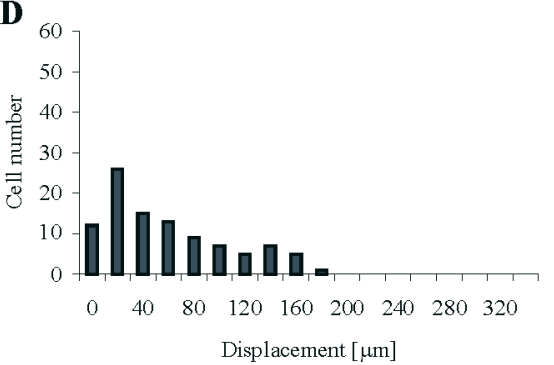

Oral mucosa keratinocytes - control conditions

B

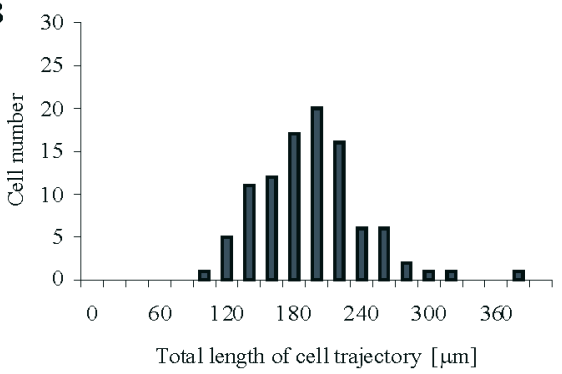

$\mathbf{E}$

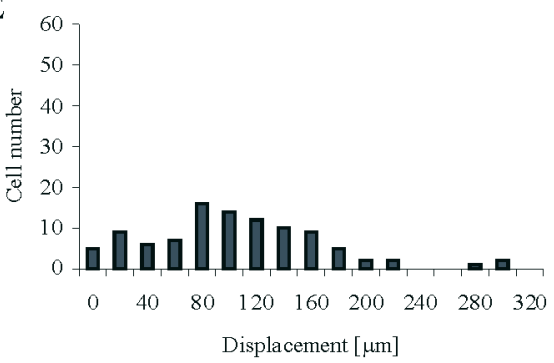

\section{Oral mucosa keratinocytes - conditioned medium}

C

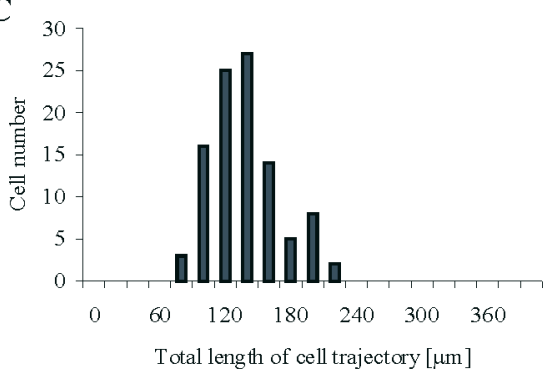

$\mathbf{F}$

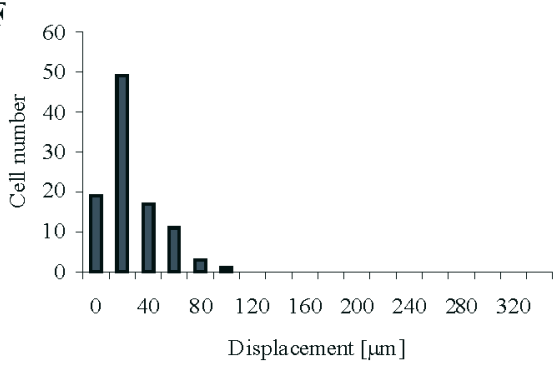

Fig. 4. Motile behavior of keratinocytes isolated from skin and oral mucosa. Values are given as the mean $(n=100) \pm S E M$. The average speed of cell locomotion is defined as the total length of cell trajectory/time of recording $(2 \mathrm{~h})$. The average rate of cell displacement is defined as the total length of cell displacement from the starting point to the final cell position/time of recording $(2 \mathrm{~h})$, the ratio of cell displacement to cell trajectory length. CDE would equal 1 for the cell moving persistently along one straight line in one direction and 0 for a random movement (FRIEDL et al. 1993; WóJCIAK-STOTHARD et al. 1995). 
Characterisation of motile activity of keratinocytes isolated from oral mucosa and skin

The determination of cell trajectories is necessary to discriminate between cell motile activity and final effective cell displacement (KOROHODA $\&$ MADEJA 1997). The positions of the cell centroid from the consecutive frames were used for generation of cell tracks. The trajectories of keratinocytes isolated from oral mucosa differed significantly in all parameters from that of the epidermal keratinocytes. In both cell types migrating cells made tortuous tracks so that their final displacement was smaller than the length of their trajectories (Fig. 3A, 3B). Analysis of these trajectories yields the results presented in Table 2 . The values of parameters that quantitatively characterise cell locomotion were estimated as described previously (KOROHODA et al. 1997; WÓJCIAK-
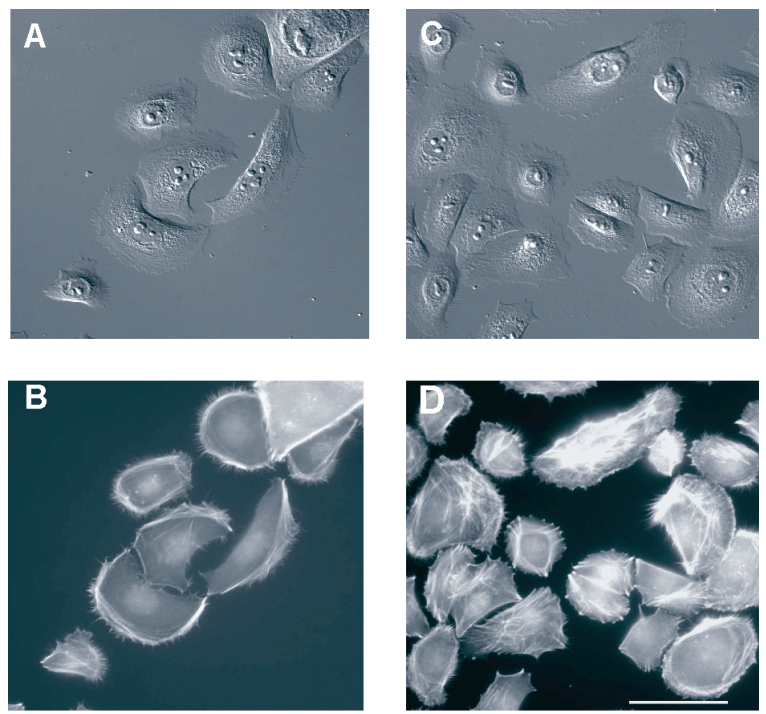

Fig. 5. Organisation of F-actin cytoskeleton in keratinocytes isolated from human oral mucosa (A, B) and skin (C,D). F-actin was stained with TRITC-phalloidin. $\mathrm{Bar}=50 \mu \mathrm{m}$. A, C - Nomarski's differential interference contrast, B,D fluorescence microscopy.

$\mathbf{A}$

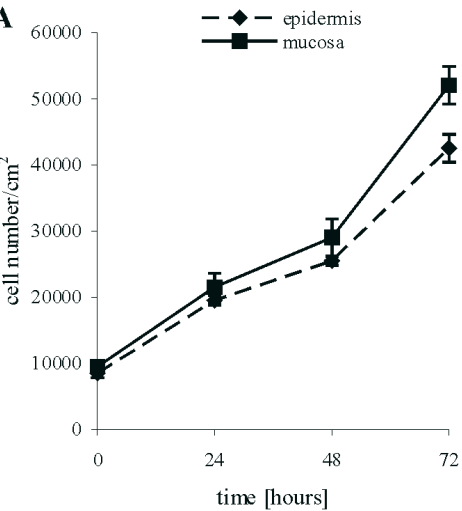

STOTHARD et al. 1995). The final cell displacement of keratinocytes isolated from oral mucosa was almost twice greater than epidermal keratinocytes (Fig. 4E, D), but total length of trajectories for both cell types differed by only about $10 \%$ (Fig. 4B, A). Migrating skin keratinocytes turned more often and their tracks were more tortuous (CDE-0.36) so that their final displacement was much smaller than the final displacement of mucosal keratinocytes migrating along more straightlines (CDE-0.55).

Also the temporal speed of cell movement, determined by measuring the distance travelled by a cell during a given time interval, was greater for mucosal keratinocytes $(1.73 \mu \mathrm{m} / \mathrm{min})$ than for epidermal keratinocytes $(1.55 \mu \mathrm{m} / \mathrm{min})$.

Actin cytoskeleton organisation in keratinocytes from skin and oral mucosa

Actin organisation differed in locomoting keratinocytes from skin and oral mucosa. In oral mucosal keratinocytes, F-actin accumulated at all surface projections and/or at cell boundaries. In skin keratinocytes actin bundles were more often present throughout the cytoplasm of cell lamella and at the border between the cell body and lamella (Fig. 5).

Comparison of the rates of proliferation of keratinocytes isolated from oral mucosa and skin

As shown in Figure 6A, the kinetics of growth of keratinocytes isolated from epidermis and oral mucosa was significantly different. Mucosa keratinocytes achieved $20 \%$ higher density after $24 \mathrm{~h}$ in in vitro culture than skin keratinocytes and these differences persisted at the same level during $72 \mathrm{~h}$.

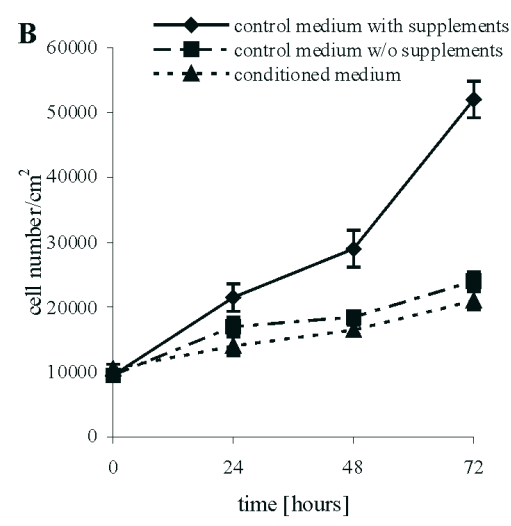

Fig. 6. Proliferation activity in keratinocyte cultures: A - cells isolated from epidermis or oral mucosa, B - isolated from oral mucosa and cultured in control conditions (positive control - KBM-2 with supplements, negative control - KBM-2 without supplements) and in conditioned medium (conditioned medium (CM) was prepared by incubating the confluent fibroblast with KBM-2 (without supplements) medium at $37^{\circ} \mathrm{C}$ overnight). Each point represents the mean of the three cultures. Bars indicate \pm SEM. 
The effect of conditioned medium (CM) prepared from oral mucosa fibroblast cultures on oral mucosa keratinocytes motility and growth

In the present model, conditioned medium from an oral mucosa fibroblast monolayer culture decreased the motile activity of oral mucosa keratinocytes. (Fig. 3C, Table 2). It was found that in the presence of conditioned medium, keratinocyte growth was significantly delayed in comparison with control medium (keratinocyte growth medium with supplements), but was at the same level as in control medium without supplements (Fig. 6B). Similar effects were observed using fibroblasts isolated from skin (data not shown)

\section{Discussion}

Wound healing in the oral mucosa is clinically different from dermal healing in terms of its speed and lack of scar formation. It has been shown that these differences may be connected with alterations in cytokine profile in the wound environment and in the inflammation stage of healing, and also with epithelial-mesenchymal interactions (GRøN et al. 2002; LEPEKHIN et al. 2002; MACKENZIE \& HILL 1984; SZPADERSKA et al. 2003).

LEIGH et al. (1987) showed that when epithelial sheets were transplanted to chronic leg ulcers, the sheets stimulated wound healing but the cells disappeared and the wound recovered by the recipient keratinocytes.

OKAZAKI et al. (2003) suggested that in epithelial differentiation the intrinsic control by epithelial cells is stronger than extrinsic regulation by mesenchymal fibroblasts.

The aim of the presented study was to compare morphology, motile activity, and proliferation of keratinocytes isolated from human skin or oral mucosa.

Image cytometry did not shown differences in parameters characterizing size and morphology of keratinocytes from both origins.

Analysis of parameters characterising cell movement revealed, however, that keratinocytes isolated from oral mucosa migrate at a higher speed than keratinocytes from skin, and their trajectories are straighter. Also, analysis of cell proliferation showed that mucosal keratinocytes grew faster than skin keratinocytes under in vitro conditions. Differences in migration and proliferative activity between mucosal and skin keratinocytes may be associated with a difference in cell differentiation between these two cell types (HATA et al. 1995).
The difference in cell motile activity corresponds to the actin organization in oral mucosa and skin keratinocytes. The oral mucosal keratinocytes displayed the F-actin distribution characteristic of fast locomoting cells (BEREITER-HAHN 1986).

Conditioned medium from cultures of oral fibroblasts was observed to decrease the growth rate of oral mucosa keratinocytes when compared with their growth rate in the medium with BPE (bovine pituitary extract), hEGF, insulin, hydrocortisone, transferrin, epinephrine and gentamycin as supplements and reduced to the level observed in the unsupplemented medium. YAEGER et al. reported that fibroblast cell membranes added to keratinocyte culture accelerate their proliferation (YAEGER et al. 1991). PAPINI et al. showed that early epidermal keratinocyte progenitors are multipotent providing first time evidence for the existence of mucin-secreting cells during epidermal development in vitro. Their study strongly suggests that both these mucin-producing cells and other keratinocytes derived from a common bipotent keratinocyte progenitor represent the final progeny of individual keratinocyte clones, but the molecular mechanism of these differentiation events is still unclear (PAPINI et al. 2003).

These observations as well as the present ones indicate the need for greater appreciation of the complex nature of conditions in co-cultures and in vivo. Besides paracrine effects of cytokines and other diffusible compounds, the direct interactions of keratinocytes with fibroblasts as well as with insoluble ECM proteins can have pivotal significance for wound healing by influencing the mitotic activity in the overlying epithelium (MAAS-SZABOWSKI et al. 2001).

There is some evidence that keratinocytes isolated from skin and from oral mucosa differ in their differentiation (BRYSK et al. 1995; MACKENZIE \& HILL 1984). Nevertheless, the clinical report of UEDA et al. shows that the grafts of oral mucosa can be used for skin wound repair (UEDA 1995). Mucosal keratinocytes that proliferate faster than skin keratinocytes under in vitro conditions may be useful for clinical wound healing when as many cells as possible are required in a short time. In addition, in accidents, when extensive skin burns make it difficult to take biopsies from skin, the oral mucosal keratinocytes can be taken for multiplications in vitro and used for skin wound healing.

\section{Conclusion}

The results presented confirmed that human oral mucosal keratinocytes can be cultured in vitro. 
They were found to grow and locomote faster than skin keratinocytes cultured in the same medium under identical experimental conditions. This can make them useful for clinical epithelial wound healing when many autologous cells are required or skin biopsies are difficult, as in some burn patients.

\section{References}

BEREITER-HAHN J. 1986. Epidermal cell migration and wound repair. (In: Biology of the Integument. Vol. 2, Vertebrates. Bereiter-Hahn J., Matoltsy A. G., Richards, K. S., eds. Springer Verlag Publishers, Berlin): 443-471.

BRYSK M. M., ARANY I., BRYSK H., CHEN S., CALHOUN K.H., TYRIHG S. K. 1995. Gene expression of markers associated with proliferation and differentiation in human keratinocytes cultured from epidermis and from buccal mucosa. Archs. Oral Biol. 40: 855-862.

Drukala J., Bandura L., Cieslik K., Korohoda W. 2001. Locomotion of human skin keratinocytes on polystyrene, fibrin, and collagen substrata and its modification by cell-to-cell contacts. Cell Transplant. 10: 765-771.

DunN G. A., BROWN A. F. 1987. A unified approach to analyzing cell motility. J. Cell Sci. Suppl. 8: 81-102.

FRIEDL P., NOBLE P. B., ZANKER K. S. 1993. Lymphocyte locomotion in three-dimensional collagen gels. Comparison of three quantitative methods for analysing cell trajectories. J. Immunol. Methods 165: 157-165.

GAllico G. G., O'CONNOR N. E., COMPTON C. C., REMENSYNDER J. P., KEHINDE O., GREEN H. 1989. Cultured epithelial autografts for giant congenital nevi. Plast. Reconstr. Surg. 84: 1-9.

GRINNELL F. 1990. The activated keratinocyte: up regulation of cell adhesion and migration during wound healing. $\mathrm{J}$ Trauma 30: 144-149.

Grøn B., Stoltze K., Andersson A., Dabelsteen E. 2002. Oral fibroblasts produce more HGF and KGF than skin fibroblasts in response to co-culture with keratinocytes. APMIS 110: 892-898.

GRULER H., NUCITELLI R. 1991. Neural creast cell galvanotaxis: new data and a novel approach to the analysis of both galvanotaxis and chemotaxis. Cell Motil. Cytoskeleton 19: 121-133.

Hata K., Kagami H., Ueda M., Matsuyama M. 1995. The characteristics of cultured mucosal cell sheet as a material for grafting; comparison with cultured epidermal cell sheet. Ann. Plast. Surg. 34: 530-538.

Kaiser H. W., StARK G. B., Kopp J., BAlCERKIEWicz A., SPILKER G., KREYSEL H. W. 1994. Cultured autologous keratinocytes in fibrin glue suspension, exclusively and combined with STS-allograft (preliminary clinical and histological report of a new technique). Burns 20: 23-29.

Korohoda W., DruKaŁa J., SRoKa J., MAdeJa Z. 1997. Isolation, spreading, locomotion on various substrata, and the effect of hypotonicity on locomotion of fish keratinocytes. Biochem. Cell Biol. 75: 277-286.

KOROHODA W., MADEJA Z. 1997. Contact of sarcoma cells with aligned fibroblasts accelerates their displacement: computer-assisted analysis of tumor cell locomotion in coculture. Biochem. Cell Biol. 75: 263-276.
LAUER G. 1994. Autografting of feeder-cell free cultured gingival epithelium - Method and clinical application. J. Cranio-Max-Fac. Surg. 22: 18-22.

LEE Y., MCINTIRE L. V., ZYGOURAKIS K. 1994. Analysis of endothelial cell locomotion: Differential effects of motility and contact inhibition. Biotechnol. Bioeng. 43: 622-634.

Leigh I. M., Purkis P. E., NAvsaria H. A., Phillips T. J. 1987. Treatment of chronic venous ulcers with sheets of cultured allogenic keratinocytes. Br. J. Dermatol. 117: 591-597.

LEPEKHIN E. GRON B., BEREZIN V., BOCK E., DABELSTEEN E. 2002. Differences in motility pattern between human buccal fibroplasts and periodontal and skin fibroplasts. Eur. J. Oral Sci. 110: 13-20.

MAAS-SZABOWSKI N., SZABOWSKI A., STARK H., ANDRECHT S., KOLBUS A., SCHORPP-KISTNER M., ANGEL P.,FUSENIG N. E. 2001. Organotypic cocultures with genetically modified mouse fibroblasts as a tool to dissect molecular mechanisms regulating keratinocyte growth and differentiation. J. Invest. Dermatol. 116: 816-820.

MACKENZIE I. C., HILL M. W. 1984. Connective tissue influences on patterns of epithelial architecture and keratinization in skin and oral mucosa of the adult mouse. Cell Tissue Res. 23: $551-559$.

NISHIMURA K. Y. ISSEROFF R. R, NUCCITELLI R. 1996. Human keratinocytes migrate to the negative pole direct current electric fields comparable to those measured in mammalian wounds. J. Cell Sci. 109: 199-207.

OKAZAKI M., YOSHIMURA K., SUZUKI Y., HARII K. 2003. Effects of subepithelial fibroblasts on epithelial differentiation in human skin and oral mucosa:heterotypically recombined organotypic culture model. Plast. Reconstr. Surg. 112: 784-792.

O'CONNOR N. E., Mulliken J. B., BANKS-SChlegel S., KEHINDE O., GREEN H. 1981. Grafting of burns with cultured epithelium prepared from autologous epidermal cells. Lancet 1: 75-78.

Papini S., Cecchetti D., CAMPani D., Fitzgerald W., GRIVEL J. C., CHEN S., MARGOLIS L. ReVOltella R. 2003. Isolation and clonal analysis of human epidermal keratinocyte stem cells in long-term culture. Stem Cells 21: 481-494.

Ronfard V., Broly H., Mitchell V., Galizia J. P., Hochart D., CHAMBON E., PELlerin P., HuART J. J. 1991. Use of human keratinocytes cultured on fibrin glue in the treatment of burn wounds. Burns 17: 181-184.

SHERIDAN R. D., ISSEROFF R. R., NUCCITELLI R. 1996. Imposition of a physiologic DC electric field alters the migratory response of human keratinocytes on extracellular matrix molecules. J. Invest. Dermatol. 106: 642-646.

SOLL D. R. 1995. The use of computers in understanding how animal cell crawl. Int. Rev. Cytol. 163: 43-104.

Sugimura Y., HATA K., TORII S., UEDA M. 1997. Transplantation of cultured mucosal epithelium: an experimental study. J. Cranio-Max-Fac. Surg. 24: 352-359.

SZPADERSKA A. M., ZUCKERMAN J. D., DIPIETRO L. A. 2003. Differential injury responses in oral mucosal and cutaneous wounds. J. Dent. Res. 82: 621-626.

UEDA M. 1995. Formation of epithelial sheets by serially cultivated human mucosal cells and their application as a graft material. Nagoya J. Med. Sci. 58: 13-28.

WÓJCIAK-StOTHARD B., MAdEJa Z., KOROHODA W., CURTIS A. S. G., WILKINSON C. 1995. Spreading and orientation of macrophage-like cells on multiple-grooved substrata. Topographical control of cell behaviour. Cell. Biol. Int. 19: 485-490.

YAeger P. C., Stiles C. D., Rollins B. J. 1991. Human keratinocyte growth-promoting activity on the surface of fibroblasts. J. Cell. Physiol. 149: 110-116. 